\title{
O TEXTO IMAGÉTICO: ESTUDO DAS FOTOGRAFIAS DO HOLOCAUSTO
}

\author{
$\underline{\text { Jéssica Pâmela Bomfim Silva }}{ }^{1}$; Girlene Lima Portela ${ }^{2}$ \\ 1. Bolsista PIBIC/FAPESB, Graduanda em Letras Vernáculas, Universidade Estadual de Feira de Santana, e-mail: \\ jelbomfim@live.com \\ 2. Orientadora, Departamento de Letras e Artes, Universidade Estadual de Feira de Santana, e-mail: \\ falecom@girleneportela.com.br
}

PALAVRAS-CHAVE: texto; fotografias; Holocausto.

\section{INTRODUÇÃO}

A fotografia surgiu há milhares de anos, depois das representações artísticas préhistóricas e das técnicas de pintura, com a mesma função de informar e transparecer o mundo e com as diferenças de registrar com conforto e realidade. O surgimento da fotografia se deu com o aperfeiçoamento da pintura, porque havia insatisfação com a falta da realidade e do conforto ao produzir as telas, como afirma Barthes (1984, p.26), “[...] para fazer os primeiros retratos (em torno de 1840), era preciso submeter o sujeito a longas poses, atrás de uma vidraça em pleno sol; tornando-se objeto, isso fazia sofrer como uma operação cirúrgica [...]”. À vista disso, com a invenção da fotografia tornouse possível produzir uma imagem de forma rápida, cômoda, sem sofrimento e eternizando os momentos através de câmera.

A fotografia evoluiu bastante desde a sua invenção, sendo de grande serventia nos registros pessoais, no fotojornalismo, na publicidade, na propaganda, tornando-se essenciais no nosso cotidiano. Quer seja para informar, recordar ou para vender, as fotografias nos rodeiam de diversas formas e já não sabemos viver sem elas.

Nesse contexto, o objetivo dessa pesquisa, foi analisar as fotografias do Holocausto. A escolha do corpus, dessa pesquisa, justifica-se pelo motivo dessas fotografias serem "testemunhas" verídicas, ou seja, memórias históricas verdadeiras da Segunda Guerra Mundial que revelam os acontecimentos ocorridos nesse período através de cópias fiéis, por isso as fotografias são importantes e precisam ser analisadas, elas não mentem, são espelhos e refletem igualmente a realidade retratada.

\section{METODOLOGIA}

Nossa pesquisa é de cunho bibliográfico e descritivo. Nesse sentido, os corpura analisados foram fotografias específicas que relatam os horrores do Holocausto. Assim, não lançamos mão de instrumentos como roteiros de entrevistas, questionários ou jornal de bordo, nos limitando apenas a uma grade de análise das referidas fotografias. No que tange o procedimento, para a execução dessa pesquisa, lançamos mão de cinco etapas complementares, descritas a seguir:

1) Produção de um banco de fotografias do Holocausto, a fim de escolher as mais adequadas à análise, considerando-se os objetivos e o lastro teórico anteriormente proposto;

2) Leituras do aporte teórico para melhor compreender as características das fotografias e o que era passível de análise, a partir do lastro teórico que ampararia as análises;

3) Levantamento das características das fotos, buscando as informações do autor da foto, legendas, fonte, cor, tamanho etc.;

4) Escolha mais minuciosa das fotografias mais adequadas ao nosso propósito; 
5) Análise das fotografias, considerando-se os objetivos e lastro teórico.

\section{ANÁLISE E DISCUSSÃO DOS RESULTADOS}

O vocábulo Holocausto advém do grego e tem por significado "sacrifício pelo fogo". Sacrifício este de homens, mulheres, crianças, que por serem judeus, ciganos, deficientes físicos e mentais, eslavos, Testemunhas de Jeová, homossexuais etc. foram encaminhados de trens superlotados para guetos e campos nazistas para morreram de exaustão, de doenças, de fome e até mesmo em câmaras de gás.

Dessa maneira, foram escolhidas cinco imagens dessa época para serem analisadas. As fotografias foram escolhidas pela bagagem histórica e pela necessidade de conservar os acontecimentos do Holocausto, através das análises fotográficas. Para tal análise, considerou-se os estudos de: Barthes (1984), Flusser (2011), entre outros. Os aspectos físicos/estruturais e os parâmetros técnicos foram baseados em Portela (2013).

Abaixo, seguem as fotografias analisadas:

Aspectos físicos/estruturais

Autor da foto: Desconhecido.

Legenda: Corpo de um prisioneiro sendo colocado em um forno crematório, no campo de Auschwitz.

Parâmetros técnicos:

Fonte: Google Imagens. Acesso em 02/03/2017, cor/ preto e branco, tamanho: $83 \mathrm{~KB}$.

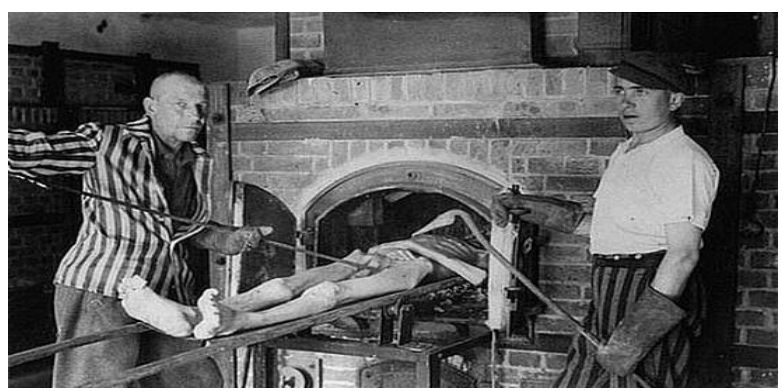

Aspectos físicos/estruturais

Autor da foto: Éric Schwab.

Legenda: Photographies D'Éric Schwab.

Parâmetros técnicos:

Fonte: AFP. PDF. Acesso em 17/09/2016, cor/ preto e branco, tamanho: $155,82 \mathrm{~KB}$.

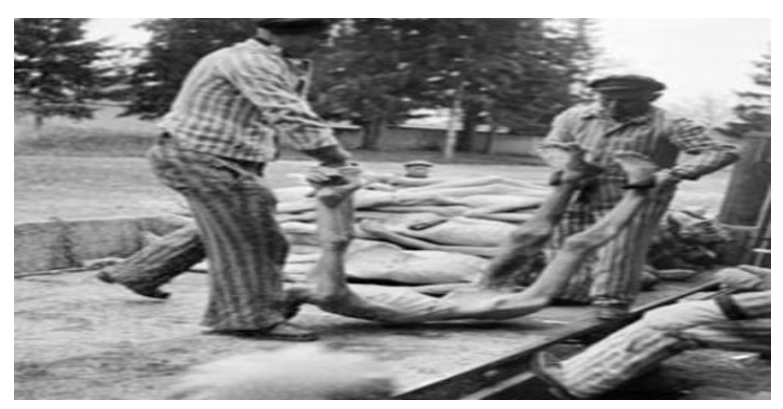

Aspectos físicos/estruturais

Autor da foto: Desconhecido.

Legenda: Mortos em campos de concentração nazista durante a Segunda Guerra Mundial.

Parâmetros técnicos:

Fonte: Google Imagens. Acesso em 17/09/2016, cor/ preto e branco, tamanho: $181 \mathrm{~KB}$.

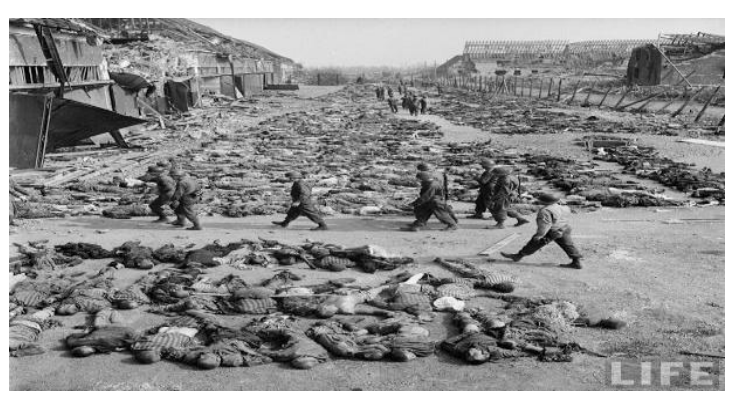

Aspectos físicos/estruturais

Autor da foto: ÉricSchwab.

Legenda: Photographies D'Éric Schwab.

Parâmetros técnicos:

Fonte: Google Imagens. Acesso em 17/09/2016, cor/ preto e branco, tamanho: $181 \mathrm{~KB}$.

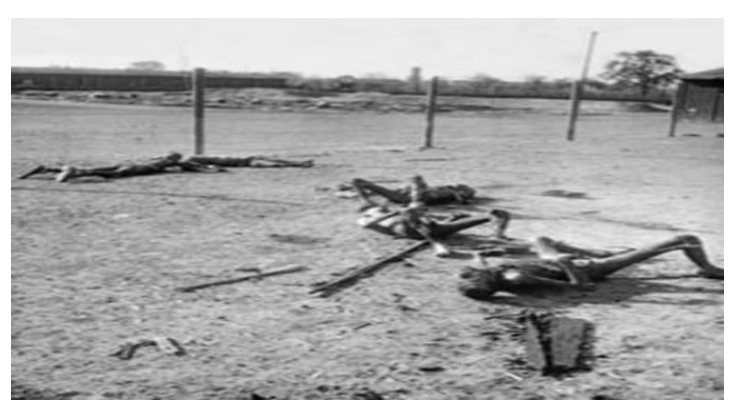




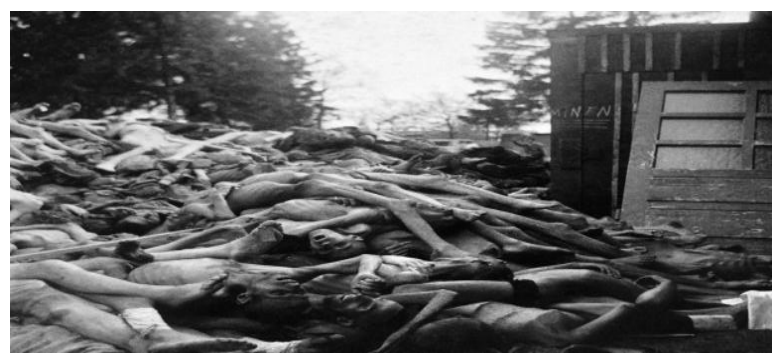

Aspectos físicos/estruturais

Autor da foto: Éric Schwab.

Legenda: Buchenwald, abril 1945.

Parâmetros técnicos:

Fonte: AFP. PDF. Acesso em 27/01/2017, cor/

preto e branco, tamanho: $279 \mathrm{~KB}$.

A fotografia normalmente traz uma carga emotiva e, segundo Portela (2013, p.4) ela é constituída por três funções: “[...] descritiva (objeto, cenário e personagens); narrativa (mostra uma ação/cena ou "conta" uma história), simbólica (representa uma ideia); expressiva: expressa emoções e estética [...]”. Essas funções são de total importância, visto que elas estão subjacentes à fotografia e ajudam em sua composição e, principalmente, em suas análises. Trazendo essas funções para as fotografias analisadas, os cenários são os campos de concentração, os personagens são os corpos esqueléticos que revelam a história dessas pessoas que sofreram nesses campos nazistas, gerando tristeza e indignação.

A fotografia também traz conceitos, que de acordo com Roland Barthes (1984), existem duas concepções inerentes nas fotografias: "Studium" e"Punctum". O primeiro advém do verbo studare e condiz com as intenções do fotógrafo e, o segundo, provém do vocábulo pungere, 'picar', 'furar', 'perfurar'. Sendo assim, as intenções do fotógrafo provocam sentimentos capazes de chegarem a mais profunda emoção do ser humano.

As fotografias acima, se encontram em cores brancas e pretas, segundo Flusser (2011, p.23), essas cores “[...] são, pois, mais 'verdadeiras'." Essas tonalidades fazem com que o receptor não se distraia com o colorido e foque no que realmente interessa na fotografia. Dessa maneira, o branco e o preto são cores reveladoras (mais que as coloridas), pois chamam a atenção para quem foi fotografado, elas são fortes, de personalidade, encantam os fotógrafos e os observadores pelo mistério que elas evidenciam. O preto e o branco são cores mais dramáticas e tendem a combinarem com o trágico, pois elas mechem com o psicológico do apreciador e aumentam a nossa capacidade de expressar os sentimentos humanos.

Outro detalhe a ser observado nas fotos são as legendas. Talvez, algumas pessoas possam pensar que as mesmas não são importantes nas fotografias, muito pelo contrário, elas esclarecem o que o leitor encontrará a priori nas imagens, ou seja, os títulos indicam uma reflexão inicial do contexto das imagens. Os títulos das fotografias analisadas situam o leitor do local e do ano em que ocorreu essa calamidade. Fato é, que a legenda é como se fosse uma "porta aberta" para que o leitor entre e comece uma reflexão que o permitirá chegar mais além: na interpretação da fotografia.Outra informação de suma importância é a autoria e os anos de produção dessas imagens, já que essas informações darão um norte ao leitor sobre o contexto, sobre o período histórico e também geográfico das fotos.

As fotografias não existiriam sem o fotógrafo, o mesmo é essencial em sua captura "O fotógrafo caça, a fim de descobrir visões até então jamais percebidas. E quer descobri-las no interior do aparelho." (Flusser, 2011, p.19). Ele torna real a cena, com situações e suas intenções, fazendo com que o receptor veja o que ele enxergou através do aparelho. $\mathrm{O}$ fotógrafo captura a memória, ele contribui para a lembrança, dispõe de tempo, paciência e prática, o mesmo tem a intenção de eternizar, através das fotografias tiradas pelo aparelho, momentos irrepetíveis. Barthes (1984, p. 56-57) afirma que: “[...] o fotógrafo, como um acrobata, deve desafiar as leis do provável ou mesmo do possível; em última instância, deve desafiar as do interessante: a foto se torna "surpreendente 
[...]". Destarte, o mesmo tem o desafio de inovar, buscar o melhor ângulo, uma luz excelente, o local mais adequado, para que a fotografia possa surpreender.

A terceira, a quarta e a quinta fotografia são do fotógrafo Éric Schwab (1910 1977). O francês foi correspondente de guerra e documentou entre abril e maio de 1945 os horrores que os aliados descobriram com a libertação dos campos de extermínio na Alemanha no período da Segunda Guerra Mundial. Através da publicação das fotos analisadas, entre outras, em jornais as pessoas puderam conhecer o que realmente se passava em um Campo de concentração alemão. Possivelmente, Éric Schwab ao capturar essas imagens, teve o objetivo de chocar o leitor, mostrando através dos corpos fotografados as consequências que a guerra trouxe.

\section{CONSIDERAÇÕES FINAIS}

O estudo realizado nos leva a concluir que as fotografias, tão presentes em nossas vidas, tem funções muito maiores que apenas rememorar, emocionar, chocar e informar. As análises realizadas apontaram que estas são signos complexos, passíveis de análises e que, por isso mesmo necessitam de mais estudos acerca de suas potencialidades, especialmente no que concerne a compreensão do mundo, do futuro que contribui para o presente que estamos vivenciando.

Sendo assim, as fotografias do Holocausto "falam" sobre um passado repleto de dores, tristezas, angústias e etc. que seres humanos foram obrigados a vivenciar. Dessa forma, são de extrema importância as análises dessas imagens, para que os pesquisadores e o público leitor tenham acesso ao período nefasto do Holocausto, através da arte fotográfica. Além dos achados nas fotografias, a conclusão a que chegamos ao realizarmos nosso estudo é a importância da pesquisa e da iniciação científica na vida do acadêmico, pois amplia as nossas visões acerca do fazer universitário.

\section{REFERÊNCIAS}

BARTHES, Roland. A câmara clara: nota sobre a fotografia. Rio de Janeiro: Nova Fronteira, 1984.

FLUSSER, Vilém. Filosofia da caixa preta: Ensaios para uma futura filosofia da fotografia. São Paulo: Annablume, 2011.

PORTELA, Girlene Lima. Olhar e (não) ver: os desafios para a análise de um texto fotográfico. 22 julho 2013.2 Disponível em: <http://www2.uefs.br:8081/girlene/verArtigo.php?idArtigo=46>. Acesso em: 11 setembro 2016. 